\title{
Understanding Perceptions about Physically Active Lifestyles among Participants in a School-sponsored "Mothers in Movement Program" in an Inner-City Community
}

\author{
Álvarez Bogantes, Carlos; Villalobos Víquez, Grettel; Vargas Tenorio, Jennifer \\ Understanding Perceptions about Physically Active Lifestyles among Participants in a School-sponsored "Mothers \\ in Movement Program" in an Inner-City Community \\ Revista Educación, vol. 45, núm. 2, 2021 \\ Universidad de Costa Rica, Costa Rica \\ Disponible en: https://www.redalyc.org/articulo.oa?id=44066178038
}

\section{(c) (1) $\Theta \Theta$}

Esta obra está bajo una Licencia Creative Commons Atribución-NoComercial-SinDerivar 3.0 Internacional. 


\title{
Understanding Perceptions about Physically Active Lifestyles among Participants in a School-sponsored "Mothers in Movement Program" in an Inner-City Community
}

Entendiendo las percepciones acerca de un estilo de vida físicamente activo de mujeres del Programa Madres en movimiento en una comunidad de atención prioritaria

Carlos Álvarez Bogantes

Universidad Nacional, Costa Rica

Redalyc: https://www.redalyc.org/articulo.oa?

ceab.03@gmail.com $\mathrm{id}=44066178038$

https://orcid.org/0000-0003-3797-7993

Grettel Villalobos Viquez

Universidad Nacional, Costa Rica

grevv26@gmail.com

iD https://orcid.org/0000-0002-4196-0759

\author{
Jennifer Vargas Tenorio \\ Universidad Nacional, Costa Rica \\ jennifervt3@gmail.com \\ iD https://orcid.org/0000-0002-2969-8129
}

Recepción: 27 Septiembre 2020

Aprobación: 03 Noviembre 2020

\begin{abstract}
:
This study is aimed at understanding perceptions regarding how physical activity impacts women who are participating in the Mothers in Movement program, an initiative sponsored by two priority schools in Heredia, Costa Rica and also examines social support received by participants and their families. The goal was to obtain input to foster interventions towards increasing physical activity among sedentary adult women and their families. This study uses a qualitative approach, obtaining data through focus groups conducted among a sample of 22 persons who are stay-at-home mothers. The study results show that, at an intrapersonal level, women feel more successful and self-sufficient when they are physically active. They are also better able to control their expectations as well as their social, persuasion and modelling abilities. On an interpersonal level, participants turned to social, instrumental, emotional and informational support and companionship when deciding to engage in physical activity. Finally, at an organizational level, the school's support in helping coordinate and execute this project was essential to promoting physical activity. This study highlighted the success of a socio-ecological model as a starting point to help sedentary mothers and their families lead more physically active lives.
\end{abstract}

KeYworDs: Social Support, Physical Activity, Stay-at-Home Mothers, Mothers, Physically Active Lifestyles.

\section{Resumen:}

El propósito de esta investigación fue entender las percepciones acerca la actividad física en mujeres participantes del programa Madres en movimiento de dos escuelas prioritarias de Heredia, así como los apoyos sociales que reciben y brindan a sus familias, con el fin de poder contar con insumos que propicien intervenciones en promoción de la actividad física en las mujeres adultas sedentarias y sus familias. Este es un estudio con enfoque cualitativo, utilizando los grupos focales para obtener la información, trabajando con un grupo de 22 mujeres que son madres y amas de casa. Los resultados de esta investigación muestran que, en la Categoría intrapersonal, las mujeres confían en su sentimiento de ser exitosas realizando actividades físicas, unido al buen uso de destrezas conductuales, dominio de las expectativas, persuasión social y modelaje. En la categoría interpersonal, utilizan los apoyos sociales, mediante el apoyo instrumental, acompañamiento, emocional e informacional para involucrarse en la actividad física. Finalmente, en la categoría organizacional, el apoyo de la escuela como medio para organizar y ejecutar el proyecto es indispensable para mantener conductas activas. En conclusión, este estudio mostró que el uso del modelo ecológico fue exitoso en lograr madres activas, con la posibilidad que apoyaran a sus familias en estilos de vida activos.

Palabras clave: Soporte social, Actividad física, Ama de casa, Madres, Estilos de vida físicamente activos. 


\section{INTRODUCTION}

Regular physical activity is known to provide many benefits for people's health, function well-being (Kohl et al., 2012); however, sedentary lifestyles continue to be on the rise, especially for single mothers who are heads of households. These trends are concerning since inactivity not only has detrimental effects on parent health and quality of life, but may also affect their children's behavior (Hosseinzadeh et al., 2015).

In order to explain sedentary behaviors in mothers, many factors come into play, such as age, gender, education, time constraints, low self-efficacy, facing barriers to exercise, lack of social support from friends and peers or spouse, rugged terrains, insecure neighborhoods and the guilt felt by mothers when they cannot be at home with their children in order to exercise (Trost et al., 2002; Mailey et al., 2014). This has led to a consensus that women's sedentary behavior is mainly influenced by factors beyond the individual level, which include interaction of individual, social and environmental factors and policies in place (Lyn, 2010).

According to the World Health Organization (WHO), the sedentary lifestyle of mothers is a priority for the healthcare system and interventions to develop active lifestyles may potentially play an important role in the development of active behaviors among mothers and their families (Yao \& Rhodes, 2015). According to recent studies, understanding the perspective of these mothers is essential for successful interventions, especially regarding stay-at-home moms, whose daily routine focuses on tending to the needs of others, even if it means sacrificing their own needs. This causes significant levels of stress, exhaustion, and frustration, and, often, leads to a low level of self-esteem (Berenzon et al., 2009; Moreno \& Johnston, 2014).

Mother-centered interventions must, therefore, be founded on theories and models focusing on the individual, their behavior and the environment and which also considers determinants of active behavior and the forms of social support that parents use to influence their children towards active lifestyles (Nyberg et al., 2015).

Lakshmi and Roseann (2013) refer to barriers, specifically time and motivation, as well as aspects of the person's surrounding environment, such as lack of affordable facilities for doing physical activity (parks, trails and free recreational facilities). Enríquez et al. (2016), mention other barriers women face, such as cost, insecurity, lack of space, embarrassment about engaging in physical activity, especially if they are no longer young, and the fact that they consider it to be hard work. However, one of the main barriers preventing mothers from engaging in physical activity is an environment where they lack of family and social support (Mailey et al., 2014).

This study was carried out to understand perceptions about physical activity among women participating in the Mothers in Movement programs at two priority schools in Heredia, Costa Rica. It provides an opportunity to gain insight about social support that these mothers receive and, in turn, provide to their families as well as helps improve interventions to promote physical activity among sedentary adult women. The framework of the study was based on a socio-ecological model designed to explore factors that influence participation in physical activity at multiple levels: intrapersonal, interpersonal and environmental (Bronfenbrenner, 1989). The objective of the study was to understand perceptions about physical activity among participants in the Mothers in Movement program, and examine factors that help promote active lifestyles among family members. 


\section{Methodology}

\section{Research Design}

This study used a qualitative methodology, with special emphasis on focus groups, which have proven to be an effective method for compiling a wide range of views and opinions on a specific topic (Horner, 2000; Darbyshire et al., 2005).

\section{Participants}

The participants were women enrolled in the Mothers in Movement program. The sample criterion (Patton, 2014) included 22 stay-at-home moms with a low socioeconomic status and a low educational level and children enrolled in two inner city schools in the canton of Heredia. The ages of the participants ranged from 28 to 50 years of age and had to have been participating in the school-sponsored program for seven months in order to participate in the focus group.

\section{Procedures}

First, an informed consent of the participating mothers was obtained. The focus group interview sessions were conducted and recorded by the researcher at a private location in the institution while the participant 's children were in class. Sessions lasted from 30 to 40 minutes.

Prior to the actual interview, the following items were explained: the objective of the study, consent to being recorded and that false names would be used to maintain their identity and comments anonymous and confidential. In addition, the terms, physical activity, exercise and sportswere explained so they could better understand the questions.

The questions created for this study and used for conducting the focus groups were developed based on finding from a bibliographic review on parental family support, a proposed objective of the study and researcher experience with a socio-ecological model (Ward et al., 2007).

\section{'Mothers in Movement' Intervention Program}

The study participants were all members of the Mothers in Movement Program. The main goal of the program was self-care through physical activity and social support in order to attain a more active life style for participating mothers and their families (Lox et al., 2010).

Program sessions were held twice weekly after they dropped their children off at school. The sessions involved three fundamental activities: a short discussion at the beginning of the session about exercise, personal and family health, physical skills, and self-esteem, followed by an exercise class, and ending with a relaxation session which reinforced strategies to be implemented with their family over the weekend using instrumental, emotional, informational, modeling support, and companionship.

In addition, a chat was created on WhatsApp to stay in touch with the participants, motivate and support them as well as respond to any questions that could arise during the course of the week. 


\section{Data Analysis}

To ensure triangulation of the collected data, after each focus group, the data was collected and transcribed by the researcher and later reviewed by an assistant (Okuda \& Gómez, 2005). After gathering a description of the data, it was then coded using open, axial and selective coding (Pitney \& Parker, 2009) to define the categories of analysis, following Ecological Model levels.

During each phase of the analysis, the categories that were determined were discussed with the research team. The methodology included researcher and theory-based triangulation, guided by an ecological model that considers constructs of multiple theories to develop the following categories: intrapersonal, interpersonal and organizational (Ward et al., 2007).

\section{Results}

This study used an ecological model as the fundamental structure for analysis of the results, considered as latest generation in the explanatory processes of behavioral change towards active lifestyles. The following categories were identified when explaining the results: their feeling of being successful and self-efficacy by carrying out physical activities, along with their use of behavioral skills, controlling expectancies, social persuasion and modeling; their use of social, instrumental, emotional and informational support, and companionship to involve in physical activity. Finally, in the organizational level, school support as a means of organizing and executing the project is essential for maintaining active behavior.

\section{SELF-EFFICACY}

According to the results of the study self-efficacy, considered to be a construct, enhances emotions among participants about their ability to succeed at being physically activity (Olivari \& Urra, 2007). Findings reveal that participants had a positive perception about feeling more physically skilled, which could significantly impact their continuity in remaining physically active in the future. Approximately $67 \%$ of participants mentioned that feeling well and loving oneself was one of the main motivations to being physically fit. Maria, for example, stated in her own words that she enjoyed 'Feeling good about myself, I feel better physically and bealthy, one really feels better.' All of the answers provided indicated a sense of overall improvement regarding being physically active (personal communication April 14, 2018). S. Torres stated '... I'm better than I was before when I didn't do any activity, it has helped me a lot, I feel lighter, I have more energy and participate in more activities; this is what I do, I come here to do Zumba' (personal communication April 14, 2018).

\section{Physical Skills}

Engaging in physical activity provides enjoyment, improves self-efficacy, increases positive expectations and puts behavioral skills into practice. All of the women believed that they were physically active and engaging in the right activity; as A. Salas stated, 'It was very interesting for me to be in the Zumba class, because I had never been able to do Zumba before. I would get lost and that would discourage me and I didn't do it. I used to only go to the gym or would go for a walk. But now that I joined, I like it very much; I am very happy and very grateful (Personal communication, April 14, 2018).. 


\section{Behavioral Skills}

As for behavioral skills, responses can be associated with Level II of cognitive theory, specifically physical and behavioral skills that lead participants to set goals as the beginning of a change in their behavior, as stated by H. Calvo: 'Well no, I think that there aren't any barriers, but that we haven't made it a goal to do that as a family, 'and another participant said: 'That's right!! A little time for us, even though it is difficult, you have to make time. I love it when classes are really energetic like today. Enjoy it and sweat a lot (Personal communication April 14, 2018).'

As an essential basis at the level of intrapersonal relationships, being able to develop an intrinsic motivation plays a determining role in behavioral skills. This is well summarized in a comment by E. Pérez (personal communication April 14, 2018): 'I really like going; since I began, I have felt very good in the group. I'm going to try to de-stress by taking a little time for myself, to improve my health. Today I didn't go because of a medical appointment and I really missed it; any project you propose, you can count on me!'

\section{Expectations}

Womens' expectations played a determining role in the processes of construction of identification towards physical activity, especially in terms of the enjoyment factor, which is one of the elements that determine adherence to physical activity (Lox, Martin \& Petruzzello). As E. Pérez (personal communication April 14, 2018) expressed it: 'Loving yourself and getting out of a routine, one is used to placing children first, home first, and the truth is that one also has the right to take a little time to indulge yourself.'

In the context of the participants, enjoyment has been considered as an essential element in continuing to engage in active behavior. Although it is not associated with any theory, it has been found that enjoyment is related to physical activity at all ages, consequently, adult women who are satisfied when practicing physical activity are more likely to keep active (Marcus \& Forsyth, 2009). As T. Moscoa (personal communication April 14, 2018) expressed it: 'Dancing is an exercise that helps a person mentally, an in terms of their health, even at home you can exercise, dance, you can do any little thing, you can do any exercise even in a small house ifyou cannot go outside.'

In addition, women indicated that the intervention was useful in increasing their personal and family physical activity and self-care. Therefore, the intervention met the expectations that participants raised when they decided to participate in the project, as exemplified by the following statement from S. Torres (personal communication April 14, 2018): 'Good for me, yes, because I didn't do any other physical activity until I started coming here so I think it has helped me a lot. I really miss exercising on the Thursdays that I don't come.'

Most of these women expect positive results from physical activity, because it creates changes in their health, their emotional state and in general in their environment. When asked if it is important to stay physically active, participants state:

E. Palma (personal communication April 14, 2018): 'Yes, many times you stay sedentary, you get used to not exercising, and when you start exercising and see changes, both in terms of health and physically, you get used to it and start a routine.

\section{Social Persuasion}

Mothers expressed satisfaction with the social relationships they experience when participating in an exercise group. According to P. Ramos, 'Personally, I had never started to do any kind of exercise, and coming here you feel better about yourself and it makes you share with friends. You are totally distracted, you get absorbed by other 
things, everything at home is forgotten here, you're somewhere else, you really relax; it has helped me a lot and I like it a lot too' (Personal communication, April 14, 2018).

In addition, they show how important the project was to them and how friendship was key in staying active: 'Hi, Grettel, count on me for whatever. In this project I not only take a little time for myself, but it also de-stresses me and the truth is that I don't feel as tired as before.'

Group union and interpersonal support were key factors for participants to stay in the group. The influence of this social support is decisive in increasing their self-efficacy, as noted by H. Fallas (personal communication April 14,2018): 'Yes, it is very important, because you come here, and well, you come here and aside from the fact that all of your friends are here, you are motivated to keep going, and although sometimes it gets complicated, we all come and taking a little time for oneself is important.'

\section{Modeling}

The effect of modeling is also noticeable. Participants perceived that the instructor had been important in improving their dedication to physical activity, constantly motivating them to continue participating in the group. P. Araya (personal communication April 14, 2018) stated that: 'For me the classes are excellent, each class is different. Grettel, you have a lot of initiative, you are creative, the music is dynamic, very good for the class; I admire you as a person, and you care about all members of the group, I think it's superfluous to tell group members not to miss this space for health, beauty, or whatever reason; it's free, and it's for us.'

The most valued types of social support were emotional and validation, which can be seen in the following comments: 'Yes, it is very important, because you come here, and well, you come here and aside from the fact that all of your friends are here, you are motivated to keep going, and although sometimes it gets complicated, we all come and taking a little time for oneself is important.' In this case, the importance of creating growth spaces for women is observed, those spaces that are theirs and in which they can dedicate themselves exclusively to themselves.

\section{COMPANIONSHIP}

Companionship was constantly provided through the creation of a WhatsApp group, which allowed the instructor to send motivational messages and information to the participants and became a means for participants themselves to express their feelings, opinions and experiences: 'Grettel you are a very good coach and instructor, the group mates are very pretty. I'm sorry to miss your classes. You give us a lot of support and your work is appreciated from the heart. Count on me if I can help you. Happy weekend.'. Good morning, blessings for you and all your family. I always remember you as a great buman being. Keep it up, and don't change. I've lost 5 kilos and I plan to lose more for my health.'

\section{INFORMATIONAL}

Informational social support was also provided through the use of the WhatsApp chat tool, which allowed short texts to be shared among participants. They were also available for use if the participants expressed any new ideas or insights or wanted to share information acquired during the sessions. The physical health promoter was essential in reminding them of fundamental data, as shown below: 'Girls, we learned so much today. Really! This is why these projects makes a difference- it's not just about coming here to dancing. It's about being informed and escaping ignorance, for a better world and for healthier and more active families.' 


\section{EMOTIONAL}

Emotional ties among participants were strengthened, and not only about exercise, but also the topics covered to improve participants' self-care and self-esteem had their effect, as the following quote from a participant makes clear: 'Good evening. The classes have been very good for me. I am very grateful to Carmen, who invited me, and to the instructor who enthusiastically gave us the class; the topics chosen for us to discuss in the group were very good.'

\section{Social Support from Mothers to Their Children}

Participant comments show social support from mothers for their children, motivating them to carry out physical activity. Half (50\%) of respondents mention that the way to motivate children is by taking them out of the house and looking for play spaces, although there may be no changes in the home environment. R. Mejía (personal communication April 14, 2018) said: 'I walk with my son and my grandchildren, and when they don't have extra classes and exams, I take them to the exercise machines or to the playing area for a little while to play ball, I've even played ball there with them and my son makes fun of me.'

Likewise, mothers indicate that they try to motivate their children to carry out physical activities. Comments by $33 \%$ of participants mention that they provide emotional and instrumental reinforcement to their children. For example, the response of M. Araya (personal communication April 14, 2018) shows her level of self-efficacy and the role of the mother as a model for behavior: 'Sometimes we try to organize them to take them to the park or the plaza to play ball, and sometimes at home we jump around in the room until they get tired and then we stop, but we try to encourage them.'

However, only a minority of the mothers state that they carry out physical activities with their children, while the great majority indicates that although they do activities together, they are not related to physical activity. Silvia observed: 'Well, on weekends, no, I really not do any activities. If I go for a walk, let's say I go to visit my sister, I walk to her place with my children, instead of using a car or taking a bus; I try to walk, but I really don't go out to exercise.'

\section{OrganizATIONAL CATEgORY}

At the organizational level, support was provided by being able to teach the sessions in the community hall or plaza near the school, so that the mothers could leave the children in classes and attend the exercise session.

The creation of these spaces allows some of the mothers to resume physical activity as a lifestyle and create their own exercise space (planned and measured out) apart from the physical activity they already carry out as part of the daily activities involved in managing their homes. This can be seen in the following statements by the participants: S. Campos (personal communication April 14, 2018): 'Well, it has been very important for me because it is like taking up something again that I had abandoned and the truth is that I feel very good, even more so with two very excellent instructors.' However, the same participants mentioned different barriers throughout the intervention, for example: 'When I don't go, it's because my daughters are sick or because I don't have anyone to take care of them. Participants justify their inability to engage in physical activities, mentioning situations such as household obligations, husband's work, lack of organization of the family to carry out these activities, or child care responsibilities; in fact, families and homes are the main barrier to physical activity. As indicated by C. Salas (personal communication April 14, 2018): 'Well, the truth is that we have never planned to do any activity like this; it's always doing things at home, picking up, maybe what you didn't do during the week, you do on Saturday. Maybe we haven't started to make time to go out as a family to do things.' 
The project therefore had to be organized to overcome these barriers, since the lack of family support was remarkable, and childcare was one of the main causes of not participating. It was thus decided to add something additional to the project by including a person who was responsible for doing physical activities with the children, so that the mothers could attend sessions in peace.

\section{Discussion}

The objective of the study was to understand perceptions of physical activity of mothers participating in the Mothers in Movement Program, as well as the social support they received and provided to their families, in order to improve the development of interventions promoting physical activity in sedentary adult women. Findings of this study support the importance of applying the socio-ecological model to understand the role of active mothers in family health, which is essential to be able to design interventions that integrate intrapersonal, interpersonal, and environmental factors that promote physical activity in boys and girls.

This research is structured around the importance of mothers as engines of change towards active lifestyles for their sons and daughters, especially in the case of housewives. Mothers usually carry out tasks to meet the needs of others, rather than their own, which leads to exhaustion, high levels of stress, and a low level of selfesteem (Berenzon et al., 2009), as has been acknowledged by the participants in this study.

Among the most important findings in this study is mothers' perception of feeling and looking healthier, which provides them with the tools needed to actually be healthier and thus take on the challenge of being models for achieving a more active family life. The fact that mothers feel healthier and more fulfilled when engaging in physical activity reflects an improvement in the variable of self-efficacy and consequently of improved self-esteem, as discussed by Lox et al. (2010).

Self-efficacy, understood as feeling successful when performing physical activity, was shown by participants when they stated that they had greater physical skills and wanted to improve even more; this contributes to enhanced self-esteem which promotes greater dedication to physical activity in participants (Peterson et al., 2013). The fact that mothers perceive themselves as capable of active behavior is one of the greatest contributors to generating such behaviors in the family through modeling (Schoeppe et al., 2016). Mother with healthy behavior can mold boys and girls to adopt values, attitudes and behaviors favoring activity.

Mothers also consistently stated that setting a good example and engaging in physical activity for the sake of the family was a reason to become involved in physical exercises, and many of the mothers prioritized involving their sons and daughters with them in the Mothers in Movement program as a way to fulfill their role like a mother of always attending to their family. This perception has been previously cited by Mailey et al. (2014) who found that mothers who find the benefits of physical activity see it as a way to help shape healthy family behaviors without feeling guilty for spending time in these activities.

Likewise, the results of this study showed that participants perceived themselves to be more active and more aware of the benefits of active life patterns, which are important contributors in promoting an increase in self-image, physical competence and self-efficacy, especially in women (González et al., 2014). When women in this group perceive themselves to be more active, it is associated with mental and psychological benefits (Berenzon et al., 2009), increase a more favorable perception of themselves as a result of participating in physical activity (Ramírez et al., 2004).

An important element of this study was finding that participants' enjoyment of performing physical activity was significant. This adds another basic element in the determining and predictive role of mothers' influence on movement behavior in childhood, making it relevant in school interventions, increasing physical activity in mothers, taking into account their needs and interests, so that they can positively influence active family behaviors (Saphier \& West, 2010; Meléndez et al., 2011).

De Ávila et al. (2018) have recognized that learning of physical skills, strengthening of behavioral skills, an emphasis on developing feelings of competence, and a system of social support for participants are other 
essential elements for a healthier life, just as the participants in this study have indicated. In this study, the perceptions and beliefs of the participants were highly relevant in generating social support in the group, not only in terms of engaging in physical activity, but also through providing emotional support in other areas of their lives.

Participants considered the main source of support for continuing in the program to be friends and the leader of the project, since they played a central role in subsequent healthy decisions, as well as in the choice of self-care strategies (Álvarez, 2016). In this sense, Peterson et al. (2013) have determined that, within existing models, participation in support networks by the women being studied offers greater opportunities to increase emotional health and quality of life, thus providing a greater impact on lifestyles in the family environment (Berenzon et al., 2009; Peterson et al., 2013).

As stated by Moreno et al. (2017) peer groups and the instructor's authority figure play a key role in determining the perception that members develop of group support and satisfaction of their psychological needs, providing models and validation for active involvement. As the participants in this study have stated, motivation, autonomy and satisfaction of being in the group are factors that have improved the members' ability to be happy (Bermejo et al., 2018).

Clearly, one of the barriers that women in this group reported was the lack of a home environment to support them. This situation has been recognized as one of the most important barriers that prevent women from continuous engagement in physical activity (Álvarez et al., 2019). It should be mentioned that mothers face other barriers, such as feeling guilty about taking time for themselves and dedicating themselves to physical activity (Mailey et al., 2014). Situation that was not perceived by mothers in this study, who recognized the direct benefit they get from active behavior.

Parents are the socializing entity that have the greatest influence on sports and playing in a child's life, with the main role in the family occupied by the mother (Sánchez \& Hernández, 2016); it is perceived by the mothers in this study, who assume the role daily, especially on the way to having a healthier family. The Mothers in Movement program encourages observational learning in the family, which lowers the risk of being overweight and provides greater opportunities for the family to be active.

The strategy of self-regulation through setting goals for physical activity outside the program and engaging in physical activity on weekends with sons and daughters, while planning courses of action to achieve goals is considered to be a strategy that provides excellent behavioral tools (Moreno et al., 2017). The mothers in this study perceived this as a way of being able to set aside additional spaces for them to actively share with the family. Developing self-regulation strategies in interventions with women should be seen as a priority to facilitate the adoption of active behaviors.

Participants perceive that they provide support to their sons and daughters using instrumental, emotional support, companionship and modeling, all of which have been recognized and positively associated with active behavior in the family (Beets et al., 2010). Use of instrumental social support by the mothers studied in this investigation was shown in the act of taking their families on weekends to engage in physical activities. Although this is the social support that mothers usually provide most frequently in other areas of daily life, it was also used and strengthened during this intervention (Ruiz et al., 2012).

On the other hand, modeling of mothers within the family is one of the constructs of the theory of social learning that was reported as an element that mothers mentioned and that was used to encourage their families to be active. In cognitive social research, the influence of active mothers has monopolized attention in the socialization process of families developing active lifestyles, based on the assumption that physically active participants could eventually modify family behaviors through observing behavior and learning from the experiences of socially important people, as established by the Ecological Model (Lox et al., 2010) and mothers are the closest family member for children to admire and emulate.

Krahnstoever et al. (2003) found that the type of support provided by parents is important in determining the future behavior of children in terms of physical activity. The participating mothers obtained significantly 
higher levels of instrumental support as compared to fathers, while fathers reported higher levels of explicit modeling than mothers. Unlike the previous study, participants in this study showed that it is possible to internalize and use different types of social support in a family environment, which provide more tools in the construction of a more active family life.

The family plays a determining role in the contribution of schools to the process of reducing the alarming levels of overweight-obesity and sedentary lifestyles of Costa Rican children. However, from Mothers in Movement Program, it is essential that priority be given to the capacities of women to assist their families along the path of healthy lifestyles. It is evident that interventions that emphasize mothers' self-care are an indispensable element in the second level of intervention, the ecological model, which supported the use of different levels of assistance by mothers in the construction of a healthier childhood in conjunction with school environments. This investigation has shown that social support is a modifiable factor that has contributed to empowerment of mothers in the use of instrumental and emotional support, and companionship, and to the figure of mothers as a model to follow in the adoption of physical exercise in the family environment.

\section{ConcLusions}

The results of this study contribute to understanding the dynamics of housewives participating in a physical activity program focused on self-care and improving social support strategies to achieve a healthier family. At the intrapersonal level, knowledge of the benefits of physical activity, a sense of personal fulfillment from looking and feeling good, along with the impact that being healthy role models for the family could have, were perceived by mothers as undeniable benefits of participating in the Mothers in Movement group. At the interpersonal level, having a group that provided them with support for physical activities, which they did not receive from their families, was an important factor in their continuing to participate in the group. In addition, the importance of support between women, which evolved from simple shared physical activity to include counseling, was emphasized. Of special note regarding social support was the perception that the participants had about the instructor's work as a permanent role model throughout the classes and as a facilitator for the different support strategies used in the program.

Regarding strategies for supporting families to achieve a healthier home environment, the importance of companionship and emotional support was perceived by participants, although they had initially not realized the importance of these factors in helping the family to be healthier.

The results of this study reveal that programs for promoting physical activity among mothers should include raising awareness among the participants about the importance of physical exercise for themselves and their families, providing group companionship networks to support continued participation, having group leaders that provides appropriate management of social support strategies, and providing the participating mothers with the necessary tools to motivate their families to adopt an active lifestyle through instrumental and emotional support as well as companionship. It is important that programs, such as this one, to promote active lifestyles involve strategies to promote a friendly social environment that meets the social, physical and emotional needs of the participants.

\section{ReferenCES}

Álvarez, C. (2016). Entendiendo los factores que determinan la actividad física en el entorno escolar desde la perspectiva de los niños y las niñas [Understanding the factors that determine physical activity in the school environment from the perspective of boys and girls]. Revista MHsalud, 13(1), 1-17. https://doi.org/10.15359/m hs.13-1.2 
Álvarez, C., Villalobos, G., Vargas, J. \& Herrera, M. (2019). Efecto del programa Escuela para Madres en Movimiento sobre la autoestima y las estrategias de apoyo social en madres de dos escuelas de atención prioritaria [Effect of the School for Mothers in Movement program on self-esteem and social support strategies in mothers from two priority schools]. Revista Ensayos Pedagógicos, 14(2), 129-150. https://doi.org/10.15359/rep.14-2.7

Beets, M. W., Cardinal, B. J. \& Alderman, B. L. (2010). Parental social support and the physical activity-related behaviors of youth: A review. Health Education \& Behavior, 37(5), 621-644. https://doi.org/10.1177\%2F109 0198110363884

Berenzon, S., Saavedra, N. \& Alanís, S. (2009). Estrategias utilizadas por un grupo de mujeres mexicanas para cuidar su salud emocional: autoatención y apoyo social [Strategies used by a group of Mexican women to care for their emotional health: self-care and social support]. Salud pública de México, 51(6), 474-481. http://www.scielo.org. $\mathrm{mx} / \mathrm{pdf} / \mathrm{spm} / \mathrm{v} 51 \mathrm{n} 6 / \mathrm{a} 05 \mathrm{v} 51 \mathrm{n} 6 . \mathrm{pdf}$

Bermejo, J., Almagro, B. \& Rebollo, J. (2018). Factores motivacionales relacionados con la intención de seguir practicando ejercicio físico en mujeres adultas [Motivational factors related to the intention to continue engaging in physical exercise in adult women]. Revista Retos, 34, 117-122. https://dialnet.unirioja.es/servlet/articulo?cod igo $=6736315$

Bronfenbrenner, U. (1989). Ecological system theory. Annals of child development, 22, 723-742.

Darbyshire, P., MacDougall, C. \& Schiller W. (2005). Multiple methods in qualitative research with children: more insight or just more? Qualitive Research, 5(4), 417-436. http://dx.doi.org/10.1177/1468794105056921

De Ávila, L., Ariza, S., Llanos, B, Herazo, Y., \& Domínguez, R. (2018). Asociación entre factores socio ambientales y la práctica de actividad física en mujeres embarazadas: estudio de corte transversal [Association between socioenvironmental factors and physical activity in pregnant women: cross-sectional study]. Revista Colombiana de Obstetricia y Ginecología, 69(1), 32-41. https://doi.org/10.18597/rcog.3004

Enríquez, M., Cruz, R., Zamarripa, J., Ceballos, O. \& Guevara, M. (2016). Nivel de Actividad física, autoeficacia, beneficios y barreras percibidas en mujeres mayores mexicanas independientes [Level of physical activity, selfefficacy, benefits and perceived barriers in older independent Mexican women]. Hispanic Health Care International, 14(1) 26-36. https://doi.org/10.1177/1540415316629680

González, S., Sarmiento, O., Lozano, O., Ramírez, A. \& Grijalba, C. (2014). Niveles de actividad física de la población colombiana: desigualdades por sexo y condición socioeconómica [Physical activity levels of the Colombian population: inequalities by sex and socioeconomic condition]. Revista Biomédica, 34(3), 447-459. https://doi. org/10.7705/biomedica.v34i3.2258

Horner, S. (2000). Using Focus Group Methods with Middle School Children. Research in Nursing \& Health, 23(6), 510-517. https://bit.ly/3gx0QTG

Hosseinzadeh, K., Niknami, S. \& Hidarnia, A. (2015).The Effects of Mothers' Self-Efficacy on Children's Physical Activity. Biotechnology and Health Sciences, 2(1), e25731. https://bit.ly/2PWJbdm

Kohl, H., Lynn, C., Lambert, E., Inoue, S., Ramadan, J., Alkandari, J., Leetongin, G., y Kahlmeier, S. (2012). The pandemic of physical inactivity: global action for public health. Revista Lancet, 380(9838), 294-305. https://d oi.org/10.1016/S0140-6736(12)60898-8

Krahnstoever, K., Cutting, M. T. \& Birch, L. L. (2003). Parents' Activity-Related Parenting Practices Predict Girls' Physical Activity. Medicine \& Science in Sports \& Exercise, 35(9), 1589-1595. https://doi.org/10.1249/01.MS S.0000084524.19408.0C

Lakshmi, J. \& Roseann, L. (2013). Cross Cultural Comparison of Attitudes towards Aging and Physical Activity. World Cultures eJournal, 19(1), 1-17. https://escholarship.org/uc/item/7rv9208v\#main

Lox, C., Martin, K. \& Petruzzello, S. (2010). The psychology of exercise. (3rd Ed). Holcomb Hathaway.

Lyn, R. (2010). Physical activity research: identifying the synergistic relationships between individual, social and environmental factors to promote active lifestyles. Health Education Research, 25(2), 183-184. https://doi.org /10.1093/her/cyq009

Mailey, E., Huberty, J., Dinkel, D. \& McAuley, E. (2014). Physical activity barriers and facilitators among working mothers and fathers. BMC Public Health, 14(657), 1-9. https://doi.org/10.1186/1471-2458-14-657 
Marcus, B. \& Forsyth, L. (2009). Motivating people to be physically active. Human Kinetics.

Meléndez, L., Olivares, S., Lera, L. \& Mediano, F. (2011). Etapas del cambio, motivaciones y barreras relacionadas con el consumo de frutas y verduras y la actividad física en madres de preescolares atendidas en centros de atención primaria de salud [Stages of change, motivations and barriers related to consumption of fruits and vegetables and physical activity in mothers of preschoolers attended in primary health care centers]. Revista Chilena de Nutrición, 38(4), 466-475. https://doi.org/10.4067/S0717-75182011000400010

Moreno, J. A., Belando, N., Huéscar, E. \& Torres, M. D. (2017). Social support, physical exercise and life satisfaction in women. Revista Latinoamericana de Psicologia, 49(3), 194-202. https://doi.org/10.1016/j.rlp.2016.08.002

Moreno, J. \& Johnston, C. (2014). Barriers to Physical Activity in Women. American Journal of Lifestyle Medicine, 8(3), 164-166. https://doi.org/10.1177/1559827614521954

Nyberg, G., Sundblom, E., Norman, A., Bohman, B., Hagberg, J. \& Elinder, L. (2015). Effectiveness of a universal parental support programme to promote healthy dietary habits and physical activity and to prevent overweight and obesity in 6 year-old children: The healthy school start study, a cluster-randomised controlled trial. Plos One, 10(2), 1-19. https://doi.org/10.1371/journal.pone.0116876

Okuda, M. \& Gómez, C. (2005). Métodos en investigación cualitativa: triangulación [Qualitative research methods: triangulation]. Revista Colombiana de Psiquiatría, 31(1), 118-124. http://www.scielo.org.co/pdf/rcp/v34n1/v 34n1a08.pdf

Olivari, C. \& Urra, E. (2007). Autoeficacia y conductas de salud [Self-efficacy and health behaviors]. Revista Ciencia y Enfermeria, 13(1), 9-15. https://bit.ly/3cqfD0b

Patton, M. (2014). Qualitative Research \& Evaluation Methods. (3rd ed.). Sage Publication.

Peterson, M., Lawman, H., Fairchild, A., Wilson, D. \& Horn, L. (2013). The association of self-efficacy and parent social support on physical activity in male and female adolescents. Health Psychology, 32(6), 666-664. https:// doi.org/10.1037\%2Fa0029129

Pitney, W. \& Parker, J. (2009). Qualitative Research in Physical Activity and the Health Professions. Human Kinetics.

Ramírez, W., Vinaccia, S. \& Suárez, R. (2004). El impacto de la actividad física y el deporte sobre la salud, la cognición, la socialización y el rendimiento académico: una revisión teórica [The impact of physical activity and sports on health, cognition, socialization and academic performance: a theoretical review]. Revista de Estudios Sociales, 18, 67-75. http://www.scielo.org.co/pdf/res/n18/n18a08.pdf

Ruiz, F., Piéron, M. \& Baena, A. (2012). Socialización de la actividad físico-deportiva en adultos: relación con familia, pareja y amigos [Socialization of physical sports activity in adults: relationship with family, partner and friends]. Revista Iberoamericana de Diagnóstico y Evaluación, 2(34), 35-59. https://www.aidep.org/03_ridep/R34/ART \%202.pdf

Sánchez, M. \& Hernández, J. (2016). Efecto de una intervención educativa sobre valores antropométricos y hábitos de actividad física de familias costarricenses de la región central en el año 2012 [Effect of an educational intervention on anthropometric values and physical activity habits of Costa Rican families in the central region in 2012]. Revista Educación, 40(1), 19-38. https://doi.org/10.15517/revedu.v40i1.21695

Schoeppe, S., Alley, S., Van, W., Bray, N., Williams, S., Duncan, M. \& Vandelanotte, C. (2016). Efficacy of interventions that use apps to improve diet, physical activity and sedentary behaviour: a systematic review. International Journal of Behavioral Nutrition and Physical Activity, 13(127), 1-26. https://doi.org/10.1186/s1 2966-016-0454-y

Saphier, J. \& West, L. (2010). How Coaches Can Maximize Student Learning. Phi Delta Kappan, 91(4), 46-50. ht tps://bit.ly/3rzT3GU

Trost, S., Owen, N., Bauman, A., Sallis, J. \& Brown, W. (2002). Correlates of adults' participation in physical activity: a review and update. Medicine and Science in Sports and Exercise, 34(12),1996-2001. https://doi.org/10.1097 /00005768-200212000-00020

Ward, D., Saunders, R., y Pate, R. (2007). Physical Activity interventions in children and adolescents. Human Kinetics. 
Carlos Álvarez Bogantes, et al. Understanding Perceptions about Physically Active Lifestyles among...

Yao, C. \& Rhodes R. (2015). Parental correlates in child and adolescent physical activity: A meta-analysis. International Journal of Behavioral Nutrition and Physical Activity, 12(10),1-38. https://doi.org/10.1186/s12 966-015-0163-y

\section{INFORMACIÓN ADICIONAL}

Cómo citar: Álvarez Bogantes, A., Villalobos Víquez, G. y Vargas Tenorio, J. (2021). Understanding Perceptions about Physically Active Lifestyles among Participants in a School-sponsored "Mothers in Movement Program" in an Inner-City Community. Revista Educación, 45(2). Recuperado de http:// doi.org/10.15517/revedu.v45i1.43591 